\title{
Sistem Informasi Penjadwalan Les Privat Menggunakan Framework Codeigniter
}

\author{
Risma Yani ${ }^{1,{ }^{\star}}$, Mansur ${ }^{1}$, Kasmawi ${ }^{1}$ \\ ${ }^{1}$ Teknik Informatika; Politeknik Negeri Bengkalis; Jl. Bathin Alam, Sei. Alam, Bengkalis-Riau \\ 28711 Indonesia, Telp.(+62766) 24566. Fax.(+62766) 8001000 \\ email: rismayani0628@gmail.com,mansur@polbeng.ac.id, kasmawi@polbeng.ac.id
}

*Korespondensi: e-mail : rismayani0628@gmail.com

Diterima: 18 Oktober 2020; Review: 30 Oktober 2020; Disetujui: 5 November 2020

Cara sitasi: Yani R, Mansur, Kasmawi. 2020. Sistem Informasi Penjadwalan Les Privat Menggunakan Framework Codeigniter. Information System for Educational and Profesionals. Vol 5(1): 11-20.

\begin{abstract}
Abstrak : Jadwal pertemuan yang tersusun serta terencana dengan baik pada les privat merupakan suatu langkah untuk meningkatkan produktivitas belajar. Les privat merupakan aktivitas belajar-mengajar yang dilakukan diluar jam sekolah, oleh karena itu penting untuk melakukan memanagement waktu dalam penyusunan jadwal les. Namun terdapat beberapa permasalahan yang sering dihadapi antara calon guru les dengan siswa terkait sistem penjadwalan. Penjadwalan yang masih dilakukan secara konvensional seperti mencatat pada media tulis yang digunakan sebagai pengingat jadwal pertemuan les antara guru dan siswa. Hal ini dapat mengakibatkan produktivitas belajar les privat menjadi tidak terpenuhi dan mengakibatkan orang tua murid melakukan pembatalan pemesanan akibat jadwal belajar yang tidak sesuai. Tujuan dari penelitian ini yaitu membangun Sistem informasi penjadwalan les privat menggunakan framework codeigniter sebagai pendukung kesuksesan calon guru privat dalam mengoptimalkan penjadwalan les yang akan mereka terbitkan. Aplikasi yang dibuat menggunakan framework codeigniter tersebut membuat sistem coding lebih tersusun dalam bentuk MVC (Model, View, Controller). Hasil dari penelitian ini yaitu dengan adanya Sistem informasi penjadwalan les privat dapat membantu pengguna jasa terkait dengan jadwal yang sudah ditentukan oleh guru privat selain itu juga memberikan kemudahan kepada guru privat dalam mengelola jadwal terkait jam dan hari pelaksanaan pada kelas paket dan les guru kelas tanpa harus melakukan pencatatan manual.
\end{abstract}

Kata Kunci : framework codeigniter, les privat, penjadwalan, sistem informasi.

Abstract:A well-structured and well-planned meeting schedule in private lessons is a step to increase learning productivity. Private tutoring is a teaching-learning activity that is carried out outside school hours, therefore it is important to manage time in the preparation of a lesson schedule. However, there are several problems that are often faced by prospective tutors and students related to the scheduling system. Scheduling is still done conventionally, such as taking notes on written media which is used as a reminder of tutoring meeting schedules between teachers and students. This can result in the productivity of learning private lessons not being fulfilled and resulting in parents canceling orders due to inappropriate study schedules. The purpose of this study is to build a private tutoring scheduling information system using a codeigniter framework to support the success of private tutor candidates in optimizing the scheduling of lessons they will publish. Applications created using the codeigniter framework make the coding system more structured in the form of an MVC (Model, View, Controller). The results of this study are that the private tutoring scheduling information system can help service users related to schedules that have been determined by private teachers besides that it also makes it easy for private teachers to manage schedules related to hours and days of 
implementation in package classes and classroom tutoring without having to do manual notetaking.

Keywords: codeigniter framework, information systems, private lessons, scheduling.

\section{Pendahuluan}

Sistem informasi sangat berperan penting dalam berbagai aspek kehidupan salah satunya pada dunia pendidikan, dimana sistem informasi memberikan pengaruh yang besar terhadap keberlangsungan aktifitas pembelajaran di sekolah maupun perguruan tinggi contohnya memberikan layanan akademik pada penjadwalan mata kuliah atau mata pelajaran, penjadwalan ujian serta informasi lainnya [1]. Penjadwalan merupakan sesuatu hal penting untuk dilakukan bagi setiap orang yang disibukkan dengan berbagai aktivitas. Bentuk positif dari terbiasanya melakukan management waktu membuat sesorang lebih disiplin dalam meningkatkan kinerja dan karir pada bidang pekerjaannya. Penjadwalan pada umumnya berkaitan dengan hari, tanggal, jam dan list kegiatan [2].

Salah satu cara untuk mengetahui apakah materi pembelajaran sudah tersampaikan dengan baik kepada siswa/i yaitu ketika mereka dapat menjelaskan kembali terhadap apa yang sudah disampaikan [3]. Pada kenyatannya seorang anak dalam memperoleh ilmu pengetahuan, pemahaman dan keterampilan lainnya tidak cukup hanya dengan memanfaatkan pendidikan formal saja [4], melainkan Banyak orang tua yang meberikan pendidikan informal dan pendidikan nonformal sesuai dengan kebutuhan masing-masing anak. Les privat merupakan salah satu contoh pendidikan nonformal, yang pelaksanaanya dilakukan diluar jam sekolah [5]. Les privat dapat sebagai pendukung potensi kemajuan ilmu pengetahuan dan skill anak [6].

Les privat mampu memberikan penguatan ekonomi terhadap masyarakat yang mampu mengambil peluang sebagai guru les privat, dengan syarat mereka telah memiliki skill serta akademik yang baik untuk berkesempatan menjadi seorang tutor maupun guru les [7]. Penjadwalan les pada guru privat di kota Bengkalis masih dilakukan secara konvensional, dimana para guru les melakukan pencatatan jadwal melalui media kertas atau alat bantu seperti alaram [8]. Hal ini juga ditandai dengan adanya aktivitas yang sering kali terulang dan sering terjadi oleh orang tua murid ketika menentukan jadwal belajar anak saat memesanan jasa guru les privat, dimulai dari orang tua murid yang menanyakan jadwal keberlangsungan les serta harga les privat yang ditetapkan oleh standar masing-masing guru. Banyaknya jumlah jam pada pertemuan akan mempengaruhi harga pembayaran les privat. Beberapa solusi yang pernah dilakukan oleh penelitian sebelumnya yaitu dengan melakukan promosi menggunakan media sosial [9], sedangkan untuk menentukan hari pertemuan les masih belum tersistem, seringkali mengalami permasalahan antara guru dan siswa akibat dari pengaturan waktu yang tidak sesuai antara keduanya, hal ini akan mengakibatkan produktivitas belajar les tidak terpenuhi. Berdasarkan masalah diatas maka dibuatlah sistem informasi penjadwalan les privat menggunakan framework codeigniter. Dengan menggunakan framework, terdapat beberapa kemudahan yang ditawarkan diantaranya memiliki standar coding, sehingga mudahkan programmer untuk ikut dalam struktur penulisan code [10].

Bahasa pemrograman yang digunakan adalah Hypertext Markup Language (HTML), Hypertext Prepocessor (PHP) yang merupakan bahasa server-side scripting menyatu dengan HTML berguna untuk membuat halaman web yang dinamis [11]. Dilanjutkan denngan penggunaan Codeigniter yang merupakan framework dengan model MVC(model-viewcontroller) dalam implementasinya Model merupakan bagaian yang bertugas untuk memisahkan antara manipulasi data dalam mengambil dan menyimpan data didalam database pada sebuah aplikasi website dinamis berbasis PHP. View merupakan bagian yang mengatur tampilan ke pengguna, dan Controller merupakan bagian yang menjembatani antar model dan view [12]. Selanjutnya utuk database sebagai media penyimpanan menggunakan MySQL (My Structured Query Language) yang merupakan multiuser database yang menggunakan bahasa Structured Query Language(SQL) [13].

Selanjutnya dalam perancangan aplikasi sistem penjadwalan les privat maka desain sistem mengguanakan Unified Modelling Language (UML) system untuk membuat Usecase Diagram, dan Activity Diagram, sedangkan untuk database menggunakan Entity Relationship Diagram (ERD). Usecase Diagram merupakan gambaran dari fungsionalitas yang diharapkan dari sebuah sistem, dan merepresentasikan sebuah interaksi antara actor dan sistem. Didalam 
Usecase terdapat actor yang merupakan sebuah gambaran entitas dari manuasia [13]. Activity Diagram merupakan bentuk permodelan dari aspek-aspek dinamis untuk mengkontruksikan sisten yang dapat di eksekusi [14].

\section{Metode Penelitian}

Metode penelitian yang digunakan pada penelitian ini yaitu dengan menggunakan metode waterfall, diantaranya melakukan Identifikasi Masalah, Pengumpulan Data (wawancara dan studi literatur), Analisa Sistem, Perancangan, Pembuatan dan Pengujian Aplikasi. Berikut langkah-langkah yang akan dilakukan adalah a) Identifikasi Masalah merupakan perumusan masalah terkait tentang kebutuhan di lapangan serta menentukan tujuan dan manfaat dari penelitian yang akan diselesaikan dari permasalahan yang diteliti serta memberikan manfaat dari hasil yang diteliti. b) Pengumpulan data yang dilakukan dengan wawancara secara langsung kepada guru les dan kepada Orang tua terkait dengan data yang dibutuhkan, data tersebut berguna sebagai acuan dalam pembuatan aplikasi. c) Analisa Sistem yang akan dilakukan pada sistem penjadwalan les privat berdasarkan analisa sistem yang sedang berjalan dan analisa sistem yang akan diusulkan. d) Perancangan Sistem, pada tahap ini dilakukan perancangan Sistem sesuai dengan kebutuhan, seperti merancang use case dan activity diagram, Entity Relationship Diagram (ERD). e) Pembuatan dan pengujian sistem, pada tahap ini sistem penjadwalan les privat akan dibangun menggunakan PHP dengan framework codeigniter dan MySql sebagai databasenya. f) Pengujian yang akan dilakukan adalah dengan melakukan menggunakan teknik black box testing.Black Box Testing merupakan pengujian untuk memeriksa apakah program sudah sesuai atau tidak dengan fungsional yang telah di definisikan tanpa harus mengetahui struktur internal dan kode program yang dipakai [15].

\section{Hasil dan Pembahasan}

Tahapan penelitian untuk menghasilkan sistem informasi, langkah-langkah yang dilaksanakan sesuai runutannya.

\section{Analisa Sistem Berjalan}

Sistem penjadwalan yang sedang berjalan pada guru les privat yang ada di Kota Bengkalis yaitu guru akan mencatat pada media tulis atau media elektronik (Alaram) yang berisikan jadwal pelaksanaan les privat yaitu jam, tanggal, bulan dan tahun. Untuk lebih jelasnya dapat dilihat pada gambar 1 .

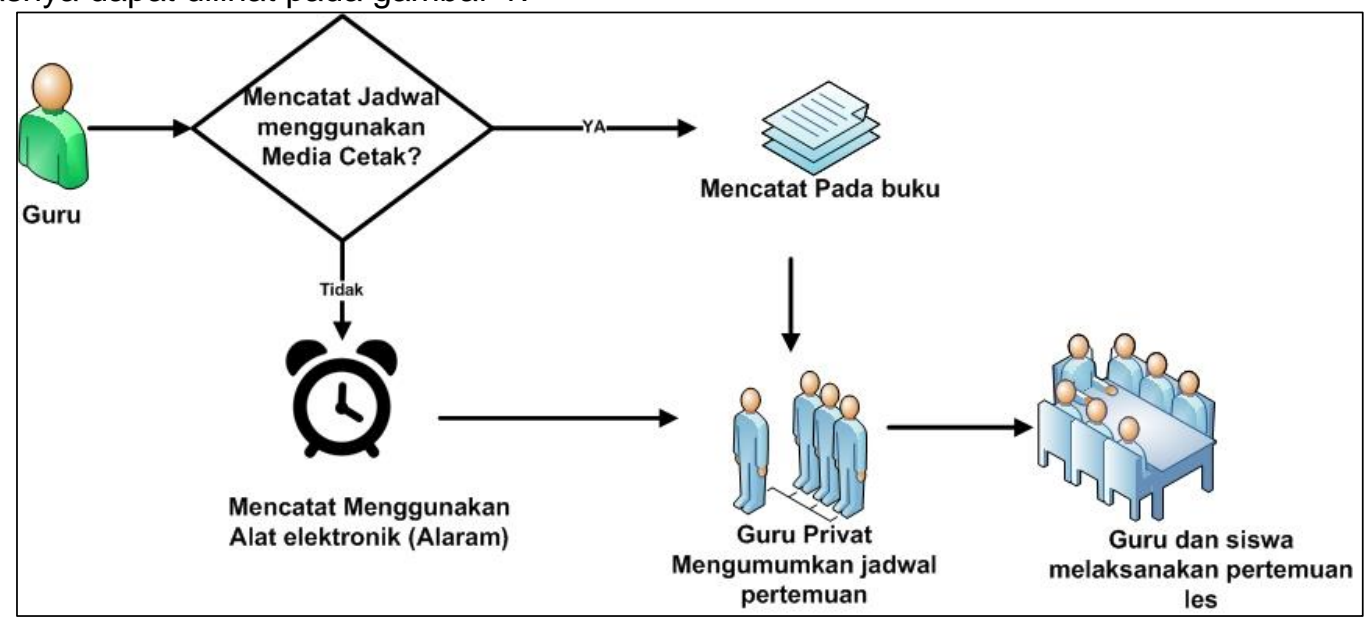

Sumber : Hasil Penelitian (2020)

Gambar 1. Alur Sistem yang sedang berjalan

\section{Analisa Sistem dan Design Usulan}

Pada sistem ini menghasilkan sebuah website tentang Sistem Penjadwalan Les Privat Menggunakan framework Codeigniter. Aplikasi ini memberikan kemudahan kepada guru les privat yang dapat memepermudahkan pekerjaan mereka dalam melakukan pencatatan penjadwalan yang dapat dilakukan secara sistem. Selain itu masyarakat kota Bengkalis dapat melakukan pemesanan jasa guru les privat sesuai dengan jadwal yang sudah di tentukan sebelumnya. Kemudahan lainnya yaitu menjadikan les privat sebagai lowongan pekerjan bagi 
semua orang yang mempunyai keahlian dibidang ilmu tertentu untuk bergabung menjadi seorang guru privat.

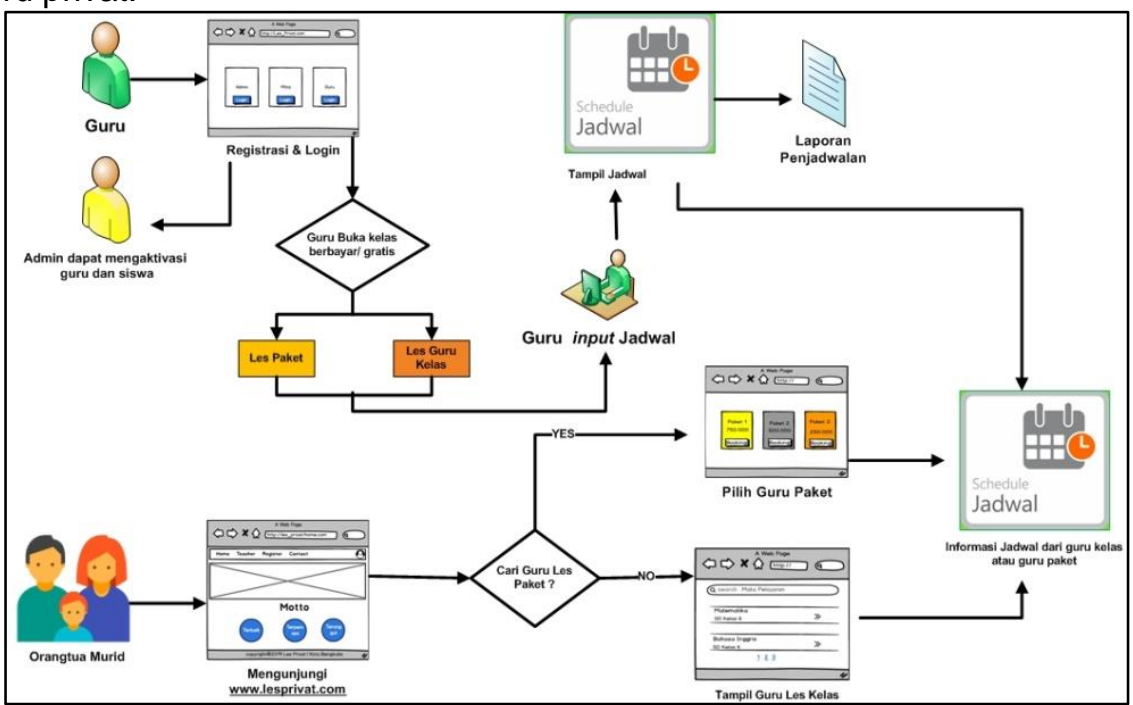

Sumber : Hasil Penelitian (2020)

Gambar 2. Alur Sistem Penjadwalan Les Privat

Berikut penjelasan gambar dari Alur Sistem Penjadwalan Les Privat.Alur sistem yang terjadi pada pengguna jasa atau orang tua murid: yaitu 1) Orang tua murid atau pengguna jasa mengunjungi laman website. Didalam website tersebut terdapat 2 kondisi apakah pengguna jasa ingin memesan jasa guru les paket? 2) Jika iya, orang tua murid dapat melihat informasi gur paket yang tersedia. 3) Jika tidak memilih guru paket maka pengguna memilih jasa les guru kelas. 4) Selanjutnya orang tua murid dapat melihat masing-masing jadwal dari guru les paket dan guru les kelas yang mereka pilih.Alur Sistem Penjadwalan Les Privat pada sisi Guru yaitu 1) Guru melakukan registrasi dan login untuk mendaftarkan dirinya dengan status pengajar. Kemudian guru dapat membuat kelas berbayar (Les Paket dan Les Guru kelas) Setiap kelas berbayar di create maka guru harus menambahkan jadwal untuk menentukan kapan Les tersebut dimulai. 2) Guru yang telah membuat jadwal kelas les privat maka dapat meng export kedalam bentuk pdf. Kemudian guru yang telah membuat jadwal akan terlihat di deretan guru les paket atau guru les kelas sesuai dengan status mengajarnya masing-masing.

Pada penelitian ini terdapat perancangan sistem. Model yang dirancang dalam sistem terdapat pada tabel 1.

Tabel 1.Perancangan Sistem

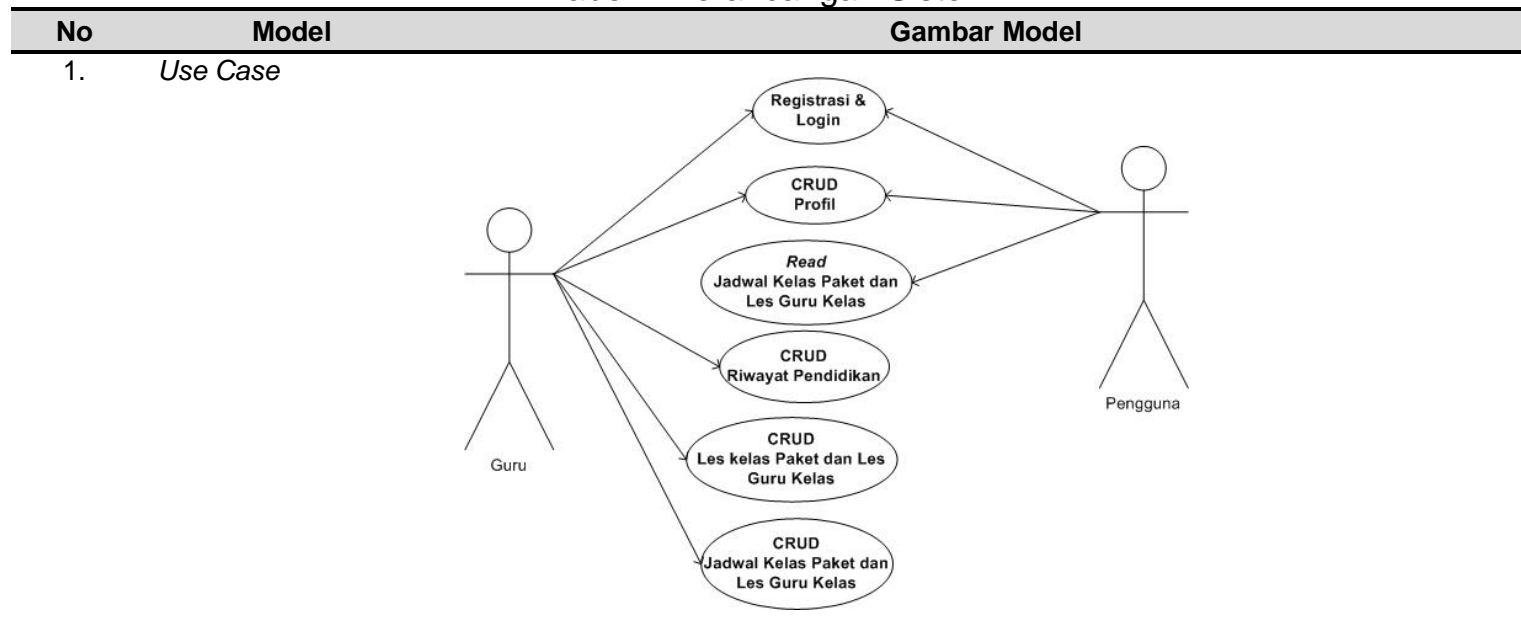

Use Case merupakan gambaran dari fungsionalitas yang diharapkan dari sebuah sistem, dan merepresentasikan sebuah interaksi antara actor dan sistem. Didalam usecaseini terdapat 2 actor yaitu guru dan pengguna. 


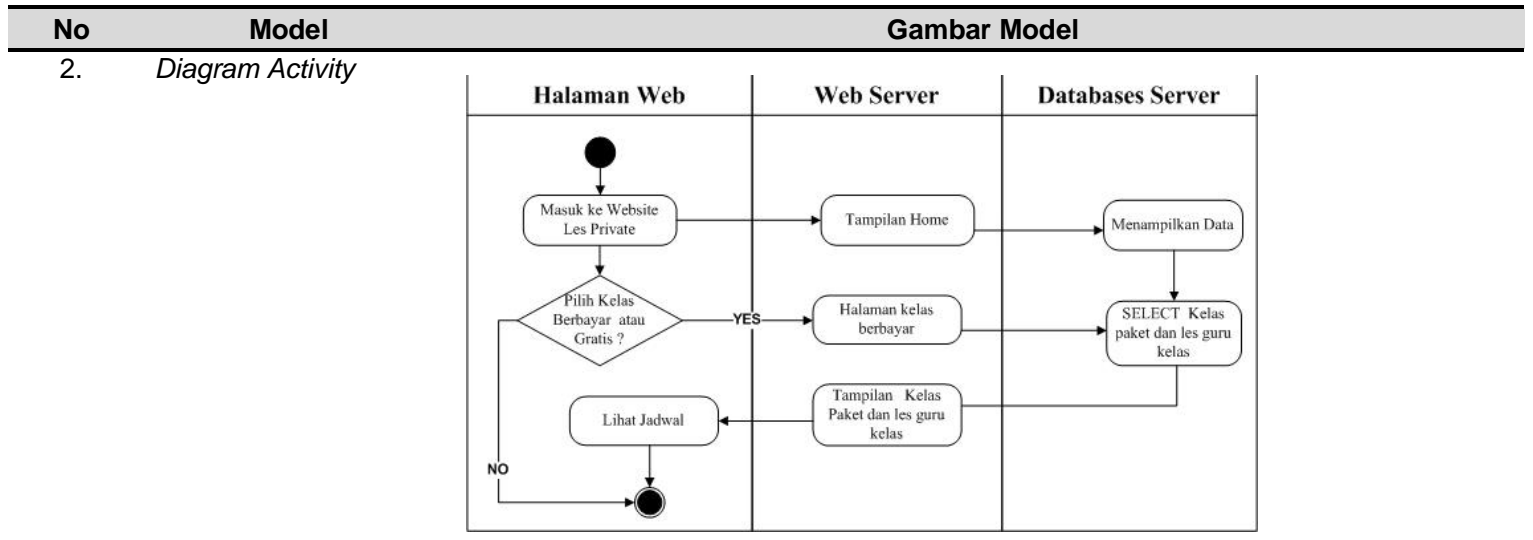

Activity ketika pengguna jasa akan melihat jadwal yang telah di tentukan oleh guru privat. Dimulai dengan masuk ke halaman website kemudian memilih halaman kelas berbyar atau gratis jika Ya maka akan menampilkan jadwal kelas privat yang sifatnya berbayar jika tidak maka akan keluar.

Sumber : Hasil Penelitian (2020)

Hasil implementasi dari Sistem informasi penjadwalan les privat yang dibangun dengan menggunakan framework codeigniter tersebut memiliki beberapa hak akses diantaranya bagian admin yang dapat meng-Input jenjang pendidikan, mata pelajaran, management akun dan menonaktifkan user. Sedangkan pada level guru (penyedia jasa les privat) bagian yang paling terpenting yaitu guru dapat melakukan pengelolaan jadwal belajar les privat selain itu guru juga dapat meng Input biodata, riwayat pendidikan, membuat kelas paket, kelas gratis, les guru kelas dan mengelola data pembookingan. Gambar 3 menunjukkan tampilan utama dari aplikasi.

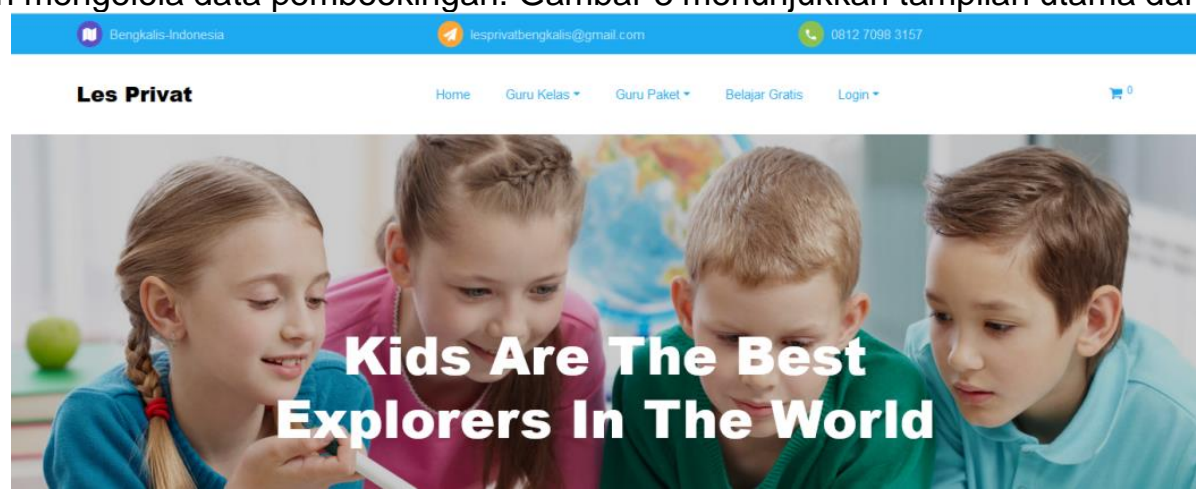

Sumber : Hasil Penelitian (2020)

Gambar 3. Tampilan Utama Aplikasi Penjadwalan Les Privat

Pada bagian siswa atau pengguna jasa dapat melihat jadwal les yang di inputkan oleh guru sebelumnya selain itu pengguna jasa juga dapat melakukan update biodata, melakukan pembookingan terhadap guru les privat, melihat quota yang tersedia, dan melihat bookingan yang expired. Pengujian atau implementasi sistem dilakukan ketika tahap pembuatan aplikasi selesai. Gambar 4 menunjukkan tampilan dari layanan aplikasi.

\section{Layanan Aplikasi}

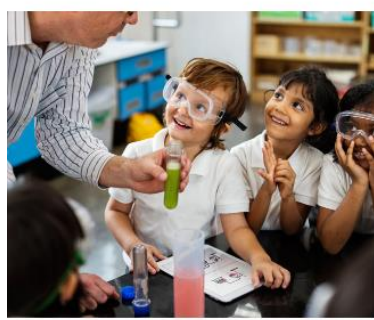

Kelas Paket Sumber : Hasil Penelitian (2020)

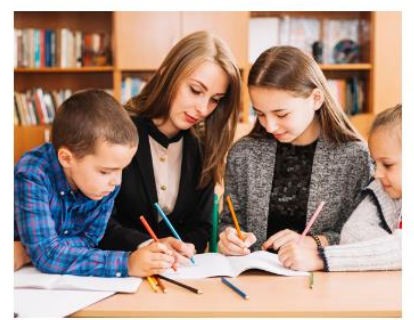

Guru Kelas

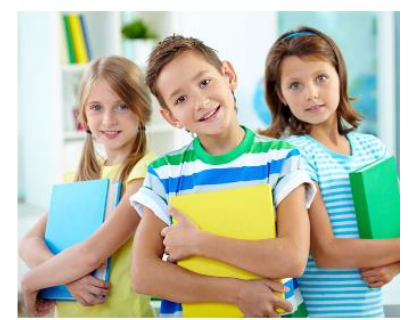

Peniadwalan Les

Gambar 4. Tampilan Layanan Aplikasi 
Sistem yang telah diselesaikan melalui tahap identifikasi masalah, perancangan atau pengkodean (bahasa pemrograman) dan pengujian maka tahap selanjutnya adalah tahap pengujian. Pengujian yang dilakukan ada dua yaitu pengujian pada web browser dan pengujianblack box. berikut pengujian pada web browser yaitu mozila firefox, google chrom dan internet explorer. Pengujian web browser terdapat pada tabel 2.

Tabel 2. Pengujian pada web browser

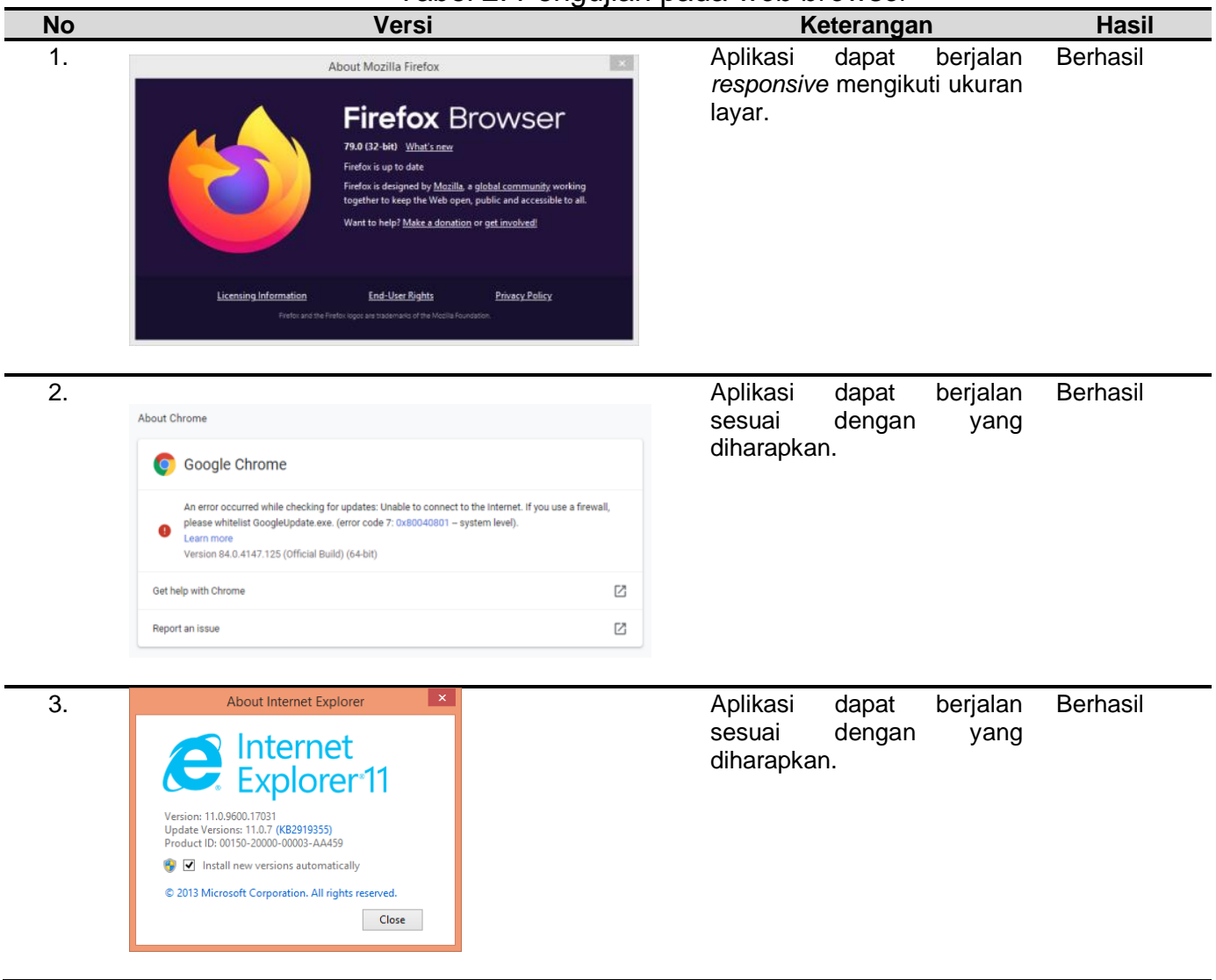

Sumber : Hasil Penelitian (2020)

Pada tahap uji coba mengunakan teknik black box testing maka akan memeriksa apakah program sudah sesuai atau tidak dengan fungsionalitas yang sudah didefinisakan sebelumnya. Berikut pengujian yang dapat dilakukan menggunakan black box testing terdapat pada tabel 3 .

Tabel 3. Pengujian black box testing

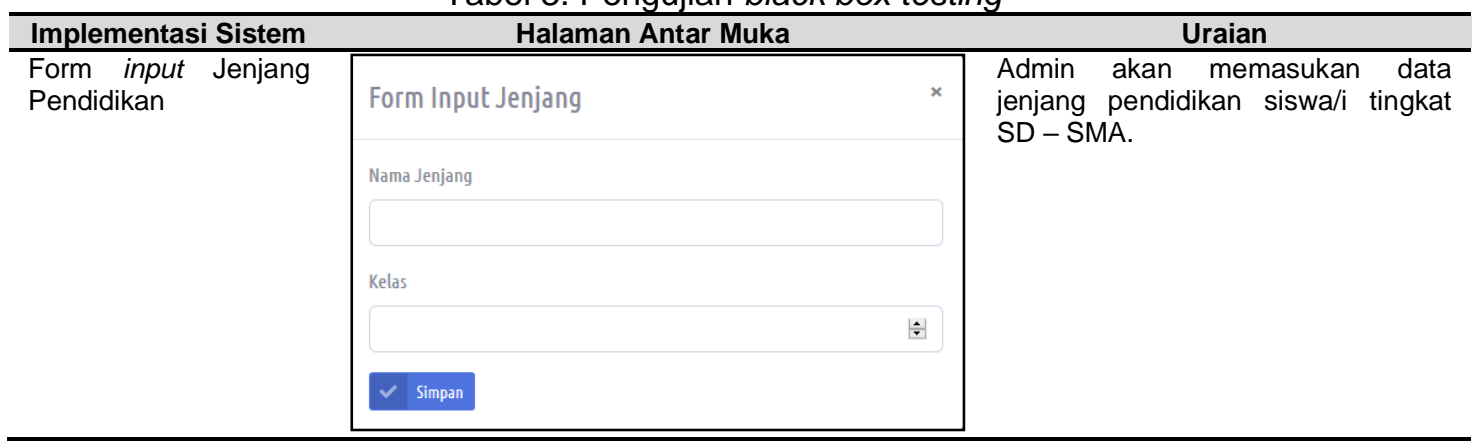


Vol. 5, No. 1, Desember 2020, 11 - 20

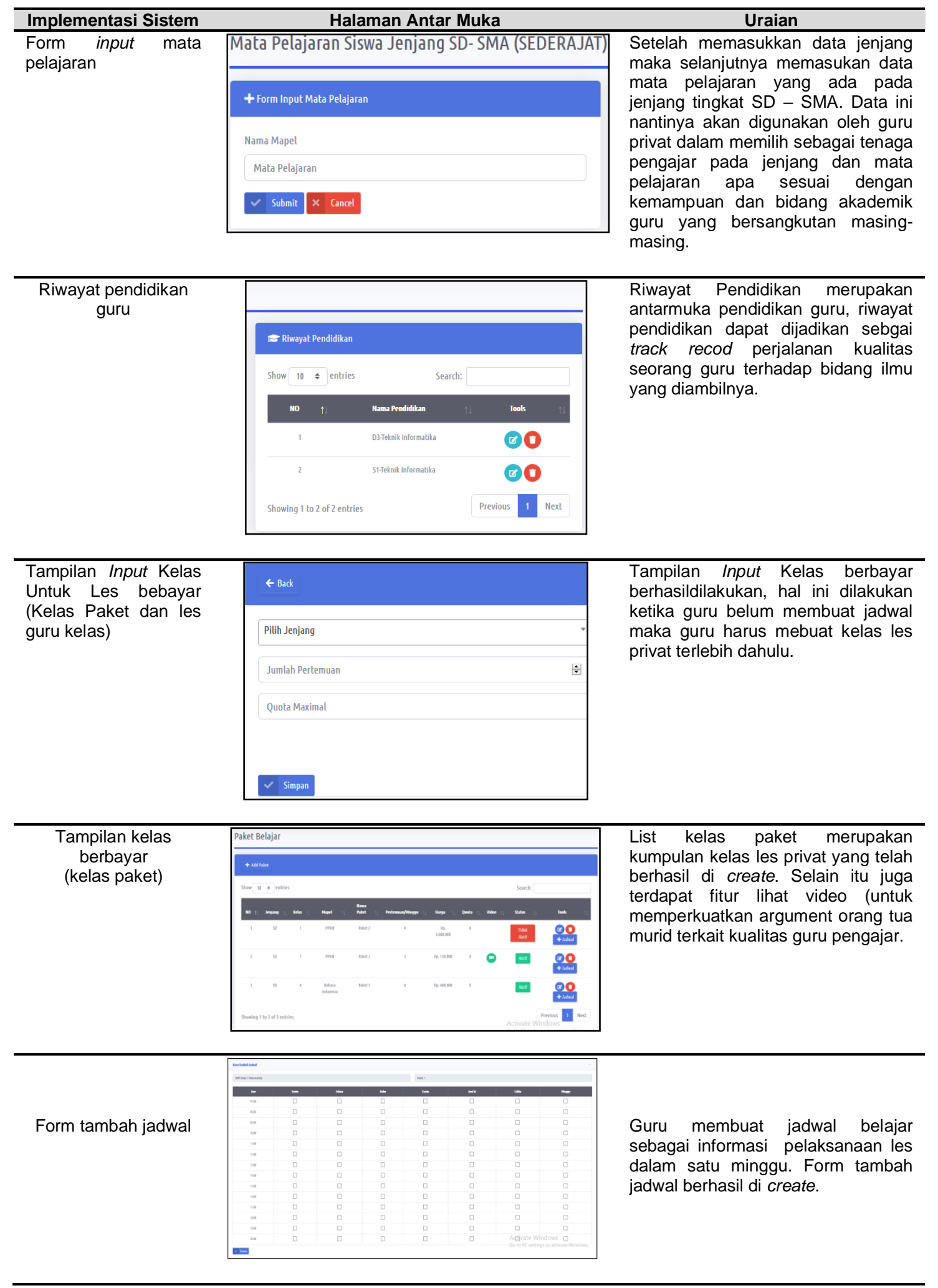




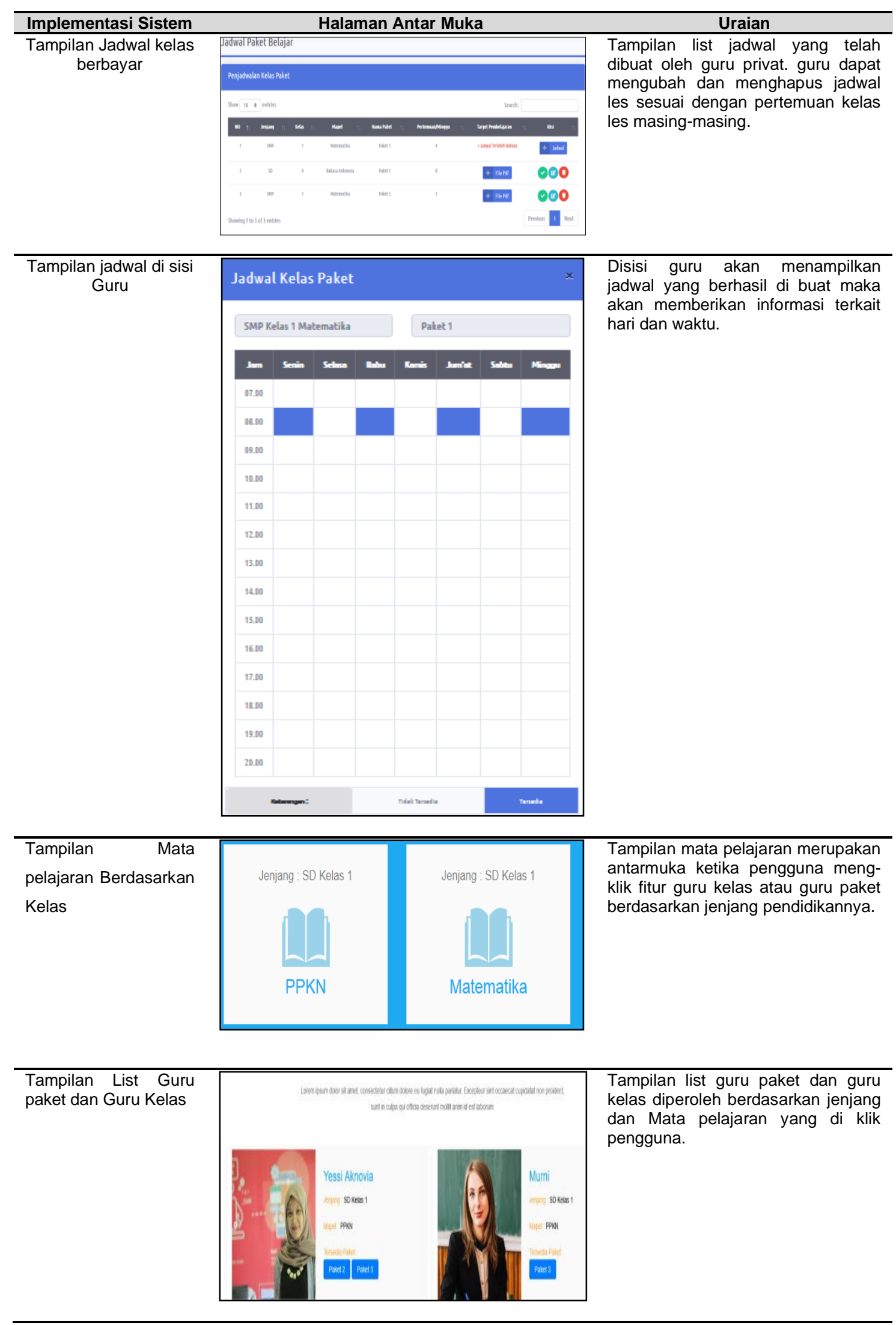


Vol. 5, No. 1, Desember 2020, 11 - 20

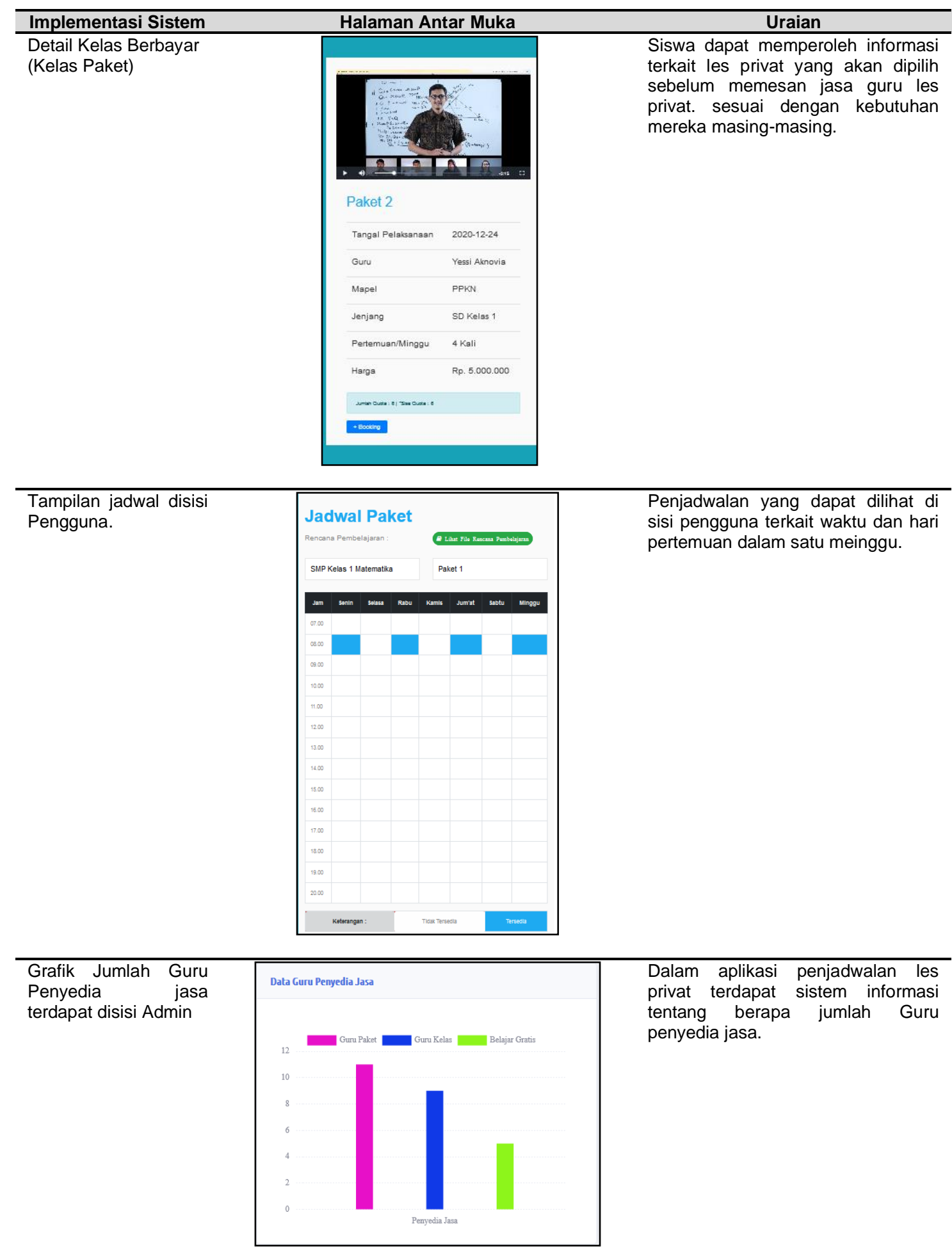

Sumber : Hasil Penelitian (2020)

\section{Kesimpulan}

Pada Sistem Informasi Penjadwalan Les Privat Menggunakan Framework Codeigniter, memiliki beberapa kesimpulan yaitu dengan adanya sistem informasi penjadwalan les privat menggunakan framework codeigniter tersebut memudahkan guru dalam pengelolaan jadwal terkait jam dan hari pelaksanaan tanpa harus direpotkan dengan pencatatan manual. Memudahkan orang tua murid atau pengguna jasa dalam memilih jasa les sesuai dengan jadwal yang sudah ditentukan oleh guru les privat sebelumnya. Dengan adanya sistem 
informasi penjadwalan les privat ini juga membantu serta Memudahkan orang tua murid dalam mengetahui serta mengingat jadwal pembelajaran les anaknya masing-masing karena informasi jadwal dapat diakses dengan mudah melalui halaman website. Selanjutnya dengan adanya aplikasi sistem informasi penjadwalan les privat ini juga dapat memudahkan guru privat dalam mempromosikan jasa lesnya agar diminati banyak orang dan meningktnya peserta les yang tergabung.

\section{Referensi}

[1] M. Mansur, "Sistem Informasi Manajemen Penjadwalan Kuliah Menggunakan Pendekatan Integer Programming," J. IIm. Ilmu Komput., vol. 1, no. 1, pp. 29-35, 2015.

[2] M. Destiningrum and Q. J. Adrian, "Sistem Informasi Penjadwalan Dokter Berbasis WEB dengan Menggunakan Framework Codeigniter ( Studi Kasus: Rumah Sakit Yukum Medical Centre)," J. TEKNOINFO, vol. 11, no. 2, pp. 30-37, 2017.

[3] S. Rofiah, "Pembelajaran PHP dengan Codeigniter Berbasis Project Based Learning," Bina Insa. ICT JOUR, vol. 5, no. 2, pp. 183-192, 2018.

[4] R. A. Machmudah, "Pengaruh Intensitas Kesertaan dalam Program Pendidikan Nonformal terhadap Prestasi Belajar Siswa SMA di Kota Malang," J. Pendidik. Hum., vol. 1, no. 2, pp. 169-176, 2013.

[5] A. K. Putra, D. R. Nyoto, and H. S. Pratiwi, "Rancang Bangun Aplikasi Marketplace Penyedia Jasa Les Private Di Kota Pontianak Berbasis Web," J. Sist. dan Teknol. Inf., vol. 5, no. 1, pp. 22-25, 2017.

[6] T. Afrizal, H. Sulaiman, and N. Isnain, "BIMBINGAN BELAJAR BUNGLON GROUP," Semin. Nas. dan Disk. Panel Multidisiplin Has. Penelit. Pengabdi. Kpd. Masy., pp. 113$118,2018$.

[7] A. Umar and A. P. Dwi, "Model Penguatan Ekonomi Masyarakat Melalui Jasa Les Privat Dan Ngaji," Discovey, vol. 5, no. 1, pp. 26-31, 2020.

[8] Rahmah and Mansur, "Desain dan implementasi sistem penjadwalan agenda berbasis android," J. Teknol. Inf. Komun. Digit. Zo., vol. 8, no. 2, pp. 196-206, 2017.

[9] Wulandari and I. Rofni, "Implementasi teknologi tepat guna kepada masyarakat," Semin. Has. Pengabdi. Masy., vol. ISSN : 261, no. November, pp. 175-180, 2018.

[10] H. Ariesna, "Pembangunan Sistem Absensi Dan Honor Guru Sma Negeri 2 Kotabumi Menggunakan," SEMBISTEK Lemb. Pengemb. Pembelajaran, Penelit. Pengabdi. Kpd. Masy., vol. 1, no. 2407-6171, pp. 15-16, 2014.

[11] M. Rendy, R. Widodo, and M. R. Zainuddin, "Sistem Informasi Dan Pengolahan Data Kursus Mobil Berbasis Web Dengan Sms Gateway Di Armada Pasuruan," J. Inform. Merdeka Pasuruan, vol. 1, no. 3, pp. 85-104, 2016.

[12] E. Nike and A. Qoiriah, "' Go - Teacher' Sistem Pencarian Guru Les Privat Berbasis Web," J. Manaj. Inform., vol. 6, pp. 91-98, 2016.

[13] M. T. Prihandoyo, "Unified Modeling Language (UML) Model Untuk Pengembangan Sistem Informasi Akademik Berbasis Web," J. Pengemb. IT, vol. 3, no. 1, pp. 126-129, 2018.

[14] F. Sidiq and W. M. Pradnya, "Sistem Informasi Akuntansi Pada Bimbingan Belajar Cetta Les Dan Private Gunungkidul," Inf. Syst. J., vol. 1, no. 1, pp. 19-23, 2018.

[15] F. C. Ningrum, D. Suherman, S. Aryanti, and H. A. Prasetya, "Pengujian Black Box pada Aplikasi Sistem Seleksi Sales Terbaik Menggunakan Teknik Equivalence Partitions," Inform. Univ. Pamulung, vol. 4, no. 4, pp. 125-130, 2020. 